Article

\title{
Enhancing the Antibacterial Properties of PVDF Membrane by Hydrophilic Surface Modification Using Titanium Dioxide and Silver Nanoparticles
}

\author{
Kajeephan Samree ${ }^{1}$, Pen-umpai Srithai ${ }^{1}$, Panaya Kotchaplai ${ }^{2}$, Pumis Thuptimdang ${ }^{3,4}$, \\ Pisut Painmanakul 5,6,7, Mali Hunsom ${ }^{8}$ and Sermpong Sairiam 1 ,*iC
}

1 Department of Environmental Science, Faculty of Science, Chulalongkorn University, Bangkok 10330, Thailand; kajeephan0603@gmail.com (K.S.); s.penumpai@gmail.com (P.-u.S.)

2 Institute of Biotechnology and Genetic Engineering, Chulalongkorn University, Bangkok 10330, Thailand; p.kotchaplai@gmail.com

3 Department of Chemistry, Faculty of Science, Chiang Mai University, Chiang Mai 50200, Thailand; pumis.th@gmail.com

4 Environmental Science Research Center, Faculty of Science, Chiang Mai University, Chiang Mai 50200, Thailand

5 Department of Environmental Engineering, Faculty of Engineer, Chulalongkorn University, Bangkok 10300, Thailand; pisut114@hotmail.com

6 Research Program on Development of Technology and Management Guideline for Green Community, Center of Excellence on Hazardous Substance Management (HSM), Bangkok 10330, Thailand

7 Research Unit on Technology for Oil Spill and Contamination Management, Chulalongkorn University, Bangkok 10330, Thailand

8 Academy of Science, The Royal Society of Thailand, Office of the Royal Society, Dusit, Bangkok 10300, Thailand; mhunsom@gmail.com

* Correspondence: sermpong.s@chula.ac.th

Received: 21 July 2020; Accepted: 14 October 2020; Published: 15 October 2020

\begin{abstract}
This work investigates polyvinylidene fluoride (PVDF) membrane modification to enhance its hydrophilicity and antibacterial properties. PVDF membranes were coated with nanoparticles of titanium dioxide $\left(\mathrm{TiO}_{2}-\mathrm{NP}\right)$ and silver (AgNP) at different concentrations and coating times and characterized for their porosity, morphology, chemical functional groups and composition changes. The results showed the successfully modified PVDF membranes containing $\mathrm{TiO}_{2}-\mathrm{NP}$ and AgNP on their surfaces. When the coating time was increased from 8 to $24 \mathrm{~h}$, the compositions of Ti and $\mathrm{Ag}$ of the modified membranes were increased from $1.39 \pm 0.13$ to $4.29 \pm 0.16$ and from $1.03 \pm 0.07$ to $3.62 \pm 0.08$, respectively. The water contact angle of the membranes was decreased with increasing the coating time and $\mathrm{TiO}_{2}-\mathrm{NP} / \mathrm{AgNP}$ ratio. The surface roughness and permeate fluxes of coated membranes were increased due to increased hydrophilicity. Antimicrobial and antifouling properties were investigated by the reduction of Escherichia coli cells and the inhibition of biofilm formation on the membrane surface, respectively. Compared with that of the original PVDF membrane, the modified membranes exhibited antibacterial efficiency up to $94 \%$ against $E$. coli cells and inhibition up to $65 \%$ of the biofilm mass reduction. The findings showed hydrophilic improvement and an antimicrobial property for possible wastewater treatment without facing the eminent problem of biofouling.
\end{abstract}

Keywords: polyvinylidene fluoride membrane (PVDF); titanium dioxide nanoparticles $\left(\mathrm{TiO}_{2}-\mathrm{NP}\right)$; silver nanoparticles (AgNP); antibacterial property; antifouling property 


\section{Introduction}

Nowadays, the number of industries is rapidly increasing, thereby posing the risk of serious water pollution. Membrane filtration is among the most popular methods for sustainable wastewater treatment because of its advantages including no phase changes or chemical addition, simple operation, and relatively low energy consumption [1]. Normally, membranes are typically fabricated from hydrophobic materials such as polyvinylidene fluoride (PVDF), polytetrafluoroethylene (PTFE), polyethylene (PE), or polypropylene (PP). Of all the materials used, PVDF is generally applied as a membrane material due to its thermal stability, excellent chemical resistance, and good membrane-forming ability [2]. However, PVDF is a semi-crystalline polymer with repeating units of $-\mathrm{CH}_{2}-\mathrm{CF}_{2}-$, which form hydrophobic structures that can make the membrane more prone to fouling [3-5]. Hydrophobic PVDF membrane is susceptible to fouling when the contacting aqueous solution contains hydrophobic species such as protein, resulting in easy absorption on the membrane surface or blockage of the membrane pores leading to decreased permeability [6,7]. Membrane biofouling involves the attachment of microorganisms on the membrane surface to form biofilm, a cluster of cells and their produced extracellular polymeric substances (EPS), which can significantly decrease the separation performance of the membrane [1]. Biofilm and its associated EPS are mainly responsible for the membrane water flux decline since their coverage on the membrane surfaces can block membrane pores and increase water transport resistance [8]. This can shorten the working life of the membrane, increase the operation cost, and finally restrict successful applications. To solve this problem, the membrane hydrophilicity must be increased to induce fouling resistance, thereby preventing the attachment of microbial cells along with the adsorption and deposition of hydrophobic pollutants onto the membrane surface [9].

There have been many attempts at the modification of the hydrophilic layer on the existing membrane surface in order to enhance the hydrophilicity, antibacterial properties and membrane performance, resulting in more efficient membrane applications such as water and wastewater treatment [10-12]. One of the most common and effective techniques to increase the hydrophilicity on the membrane surface is the addition of inorganic nano-/micro-particles including $\mathrm{SiO}_{2}, \mathrm{TiO}_{2}$, $\mathrm{Al}_{2} \mathrm{O}_{3}$, and $\mathrm{ZrO}_{2}$, which contain an abundance of polar groups on their particle surfaces [12,13]. One of the most popular inorganic particles used is titanium dioxide nanoparticles $\left(\mathrm{TiO}_{2}-\mathrm{NP}\right)$ because of its non-toxicity, low cost, and superhydrophilicity [14]. Furthermore, the catalytic activity of $\mathrm{TiO}_{2}-\mathrm{NP}^{-}$ was proved to be capable of killing a wide range of microorganisms including endospores, as well as fungi, algae, protozoa, and viruses [15]. For decades, silver nanoparticles (AgNP) have been generally used as an effective broad-spectrum biocide to functionalize filtration membrane surfaces for biofouling mitigation [16,17]. The antibacterial mechanism of AgNP, as reported in previous literature, is the release of silver ions $\left(\mathrm{Ag}^{+}\right)$that can induce cell membrane damage, promote generation of reactive oxygen species (ROS) and disrupt adenosine triphosphate (ATP) production and DNA replication, ultimately causing the death of bacteria [18]. For the purpose of enhancing the membrane fouling, the changes of membrane properties during the membrane preparation process and surface membrane modification were mainly employed. A previous study has shown that AgNPs deposited on PVDF membrane surface by physical vapor deposition could enhance the antibacterial properties and decrease bacteria growth [19]. However, the modification of PVDF membrane by $\mathrm{TiO}_{2}-\mathrm{NP}$ and AgNP using the dipped coating technique still suffers from a research gap requiring improvement. Also, the contamination of Escherichia coli still poses serious public health issues and numerous economic losses [20]. Therefore, $\mathrm{TiO}_{2}-\mathrm{NP} / \mathrm{AgNP}$-modified PVDF membrane could be useful for the treatment of wastewater contaminated with E. coli. By using this modification method, the membrane performance could be improved for long term use, thereby offering a more sustainable wastewater treatment technology.

This study aims to enhance the antibacterial and antifouling properties of the PVDF membrane modified by $\mathrm{TiO}_{2}-\mathrm{NP}$ and AgNP using the dipped coating method. The modified membrane was characterized by scanning electron microscopy (SEM) with energy dispersive X-ray spectroscopy 
(EDS) before being identified for its morphology, contact angle, and porosity. By using E. coli as a model strain, the antibacterial property and biofilm formation inhibition of the modified membranes were investigated.

\section{Methodology}

\subsection{Chemicals and Materials}

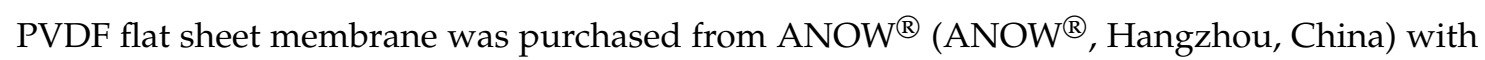
the membrane specifications already reported by the manufacturer (Table 1). A commercial TiO $-\mathrm{NP}_{2}$ and AgNP were supplied from Prime Nanotechnology (Bangkok, Thailand). The properties of TiO $-\mathrm{NP}^{-}$ and AgNP as obtained from the manufacturer are summarized in Table 2. Deionized (DI) water was used for solution preparation.

Table 1. Specifications of the polyvinylidene fluoride (PVDF) membrane.

\begin{tabular}{cc}
\hline Pore Size $(\mu \mathrm{m})$ & 0.45 \\
Membrane Porosity $(\%)$ & 80 \\
Thickness $(\mu \mathrm{m})$ & 110 \\
Color & White \\
\hline
\end{tabular}

Table 2. Properties of titanium dioxide and silver nanoparticles $\left(\mathrm{TiO}_{2}-\mathrm{NP}\right.$ and $\left.\mathrm{AgNP}\right)$.

\begin{tabular}{|c|c|c|}
\hline Properties & $\mathrm{TiO}_{2}-\mathrm{NP}$ & AgNP \\
\hline Appearance & White Powder & Yellow Brown Colloid \\
\hline Crystalline Structure & $80 \%$ Anatase, $20 \%$ Rutile & - \\
\hline Primary Particle Size (nm) & 21 & - \\
\hline Average Particle Size (nm) & - & $5-20$ \\
\hline Particle Shape & - & Nanospheres \\
\hline $\mathrm{pH}$ & - & $6 \pm 1$ \\
\hline Specific gravity $\left(\mathrm{g} \mathrm{mL}^{-1}\right)$ & - & 1.01 \\
\hline Tamped density $\left(\mathrm{g} \mathrm{L}^{-1}\right)$ & 130 & - \\
\hline Specific surface area $\left(\mathrm{m}^{2} \mathrm{~g}^{-1}\right)$ & 50 & - \\
\hline Content $(w t \%)$ & $>99.5$ & - \\
\hline
\end{tabular}

\subsection{Experimental Procedures}

Membrane Modification via Titanium Dioxide and Silver Nanoparticles $\left(\mathrm{TiO}_{2}-\mathrm{NP}\right.$ and AgNP)

First, $\mathrm{TiO}_{2}-\mathrm{NP}$ powders were dispersed in $1 \mathrm{~L}$ of deionized (DI) water and sonicated for $15 \mathrm{~min}$ using an ultrasonic bath (DT100SH, Bandelin, Berlin, Germany) at $320 \mathrm{~W}, 35 \mathrm{kHz}$ to obtain a homogeneous $\mathrm{TiO}_{2}-\mathrm{NP}$ suspension. Second, AgNP was then added into the solution and the mixture of solution was stirred by magnetic stirrer for $3 \mathrm{~min}$. For membrane modification (Figure 1), 5 pieces of PVDF flat sheet membranes $\left(2 \times 7.5 \mathrm{~cm}^{2}\right)$ were coated by dipping into the $1 \mathrm{~L}$ of nanoparticle suspension $\left(75 \mathrm{~cm}^{2} / \mathrm{L}\right)$ The coating times $(0-24 \mathrm{~h})$ and concentrations of $\mathrm{TiO}_{2}-\mathrm{NP}$ and $\mathrm{AgNP}(0$ and 10 ppm) were varied as shown in Table 3. After that, the modified membranes were incubated in an oven (ULM700, 
Memmert, Schwabach, Germany) at $60^{\circ} \mathrm{C}$ for $1 \mathrm{~h}$ to eliminate excess liquid and kept in a desiccator to completely remove moisture before being used for analysis and further experiments.

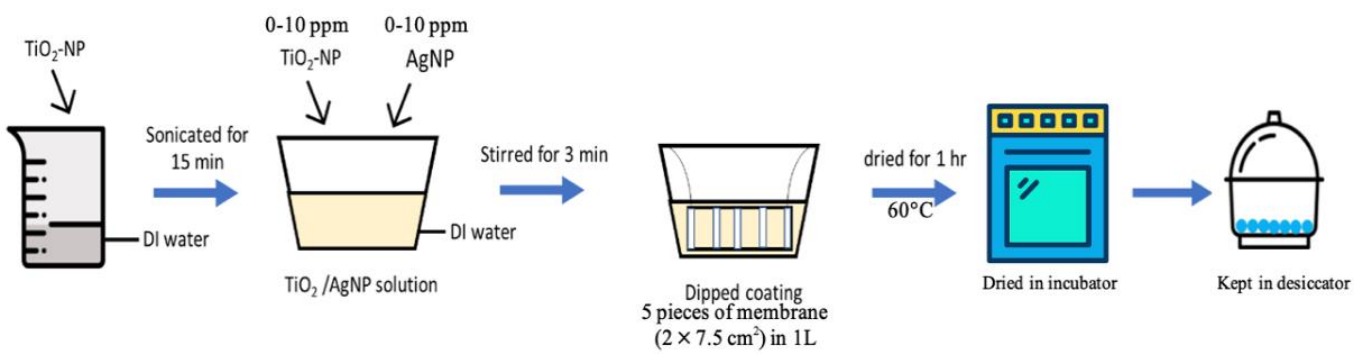

Figure 1. Schematic diagram for $\mathrm{TiO}_{2}-\mathrm{NP} / \mathrm{AgNP}$ dipped coating of $75 \mathrm{~cm}^{2}$ of flat sheet PVDF membrane into $1 \mathrm{~L}$ solution.

Table 3. Concentrations of $\mathrm{TiO}_{2}-\mathrm{NP}$ and $\mathrm{AgNP}$ and coating time for membrane modification.

\begin{tabular}{cccc}
\hline Membrane & $\begin{array}{c}\text { Concentration of } \\
\mathbf{T i O}_{2}-\mathbf{N P}(\mathbf{p p m})\end{array}$ & $\begin{array}{c}\text { Concentration of } \\
\text { AgNP }(\mathbf{p p m})\end{array}$ & Immersion Time (h) \\
\hline Original PVDF & 0 & 0 & 0 \\
M1 & & & \\
Control PVDF & 10 & 0 & 24 \\
TiO -NP & 0 & 10 & 24 \\
AgNP & 10 & 10 & 8 \\
Modified PVDF & 10 & 10 & 16 \\
M2 & 10 & 10 & 24 \\
M3 & 10 & 20 & 24 \\
M4 & 20 & 10 & 24 \\
M5 & & & \\
M6 & &
\end{tabular}

\subsection{Membrane Characterization}

\subsubsection{Contact Angle Measurement}

The membrane hydrophilicity was evaluated from the surface contact angle (OCA40, Dataphysics, Filderstadt, Germany). The water contact angle (WCA) of the membrane was measured by the sessile drop method at room temperature. One membrane sample was used for the measurement of each type of membrane (Table 3). DI water was dropped on the top surface of a dried membrane at three different positions on the single piece of membrane, and then the data were presented as a mean of the contact angles with the errors represented as standard deviations.

\subsubsection{Morphology and Chemical Composition}

Scanning electron microscopy (SEM, JSM-IT500HR, JEOL, Tokyo, Japan) and energy-dispersive X-ray spectroscopy (EDS, JEOL, Tokyo, Japan) were used to investigate the presence of $\mathrm{TiO}_{2}-\mathrm{NP}$ and AgNP as well as the surface morphology of the membrane. For each type of membrane, one membrane sample was used for the analysis. The membranes were cut into pieces and coated with gold under vacuum condition before the observation to avoid the electrostatic charging through a sputter-coater (Balzers UNION Limited, SCD040, Balzers, Liechtenstein). The chemical compositions of the membranes were analyzed three times on the same membrane sample, and the data obtained were presented as a mean with the errors represented as standard deviations. Besides, the outer surface topographies and roughness of the original and modified PVDF membranes were further observed by atomic force microscopy (AFM, SPA 400, SEIKO, Chiba, Japan). The scan area of $10 \mu \mathrm{m} \times 10 \mu \mathrm{m}$ was reported using a tapping mode. 


\subsubsection{Porosity Analysis}

Porosity of the membrane was evaluated using the gravimetric method. Each sample of the membrane $\left(1.5 \times 1.5 \mathrm{~cm}^{2}\right)$ was weighed using a digital weight balance (MS204S/01, Mettler Toledo, Greifensee, Switzerland) and recorded as the dry weight $\left(\mathrm{m}_{2}\right)$. After that, the membrane was immersed in DI water for $48 \mathrm{~h}$. Then, the sample was weighed immediately and recorded as the wet weight $\left(\mathrm{m}_{1}\right)$. The membrane porosity $(\varepsilon)$ was calculated using Equation (1) as follows [21]:

$$
\varepsilon=\left(\frac{\left(\mathrm{m}_{1}-\mathrm{m}_{2}\right) / \rho_{\text {water }}}{\frac{\left(\mathrm{m}_{1}-\mathrm{m}_{2}\right)}{\rho_{\text {water }}}+\frac{\mathrm{m}_{2}}{\rho_{\mathrm{p}}}}\right) \times 100 \%
$$

where $\mathrm{m}_{1}$ is the wet membrane weight $(\mathrm{g}), \mathrm{m}_{2}$ is the dry membrane weight $(\mathrm{g}), \rho_{\text {water }}$ is the water density $\left(0.998 \mathrm{~g} \mathrm{~cm}^{-3}\right)$, and $\rho_{\mathrm{p}}$ is the PVDF density $\left(1.74 \mathrm{~g} \mathrm{~cm}^{-3}\right)$. The data of the membrane porosity were presented as a mean with standard deviations calculated from three data of three separated membranes.

\subsubsection{Permeation Performances}

The permeation performances of both original and modified PVDF flat sheet membranes were performed by an in-house dead end filtration device (Sterlitech Corporation, CF042D, Kent, WA, USA). The effective membrane area of a filtration device is $47 \mathrm{~cm}^{2}$. For each membrane, the membranes were immersed in DI water for $24 \mathrm{~h}$ at room temperature. Prior to measurement, the membrane was pre-compacted at 4 bar for $30 \mathrm{~min}$ to obtain the initial flux. DI water was fed into the filtration device at the desired pressure, then, the permeate water obtained at different time intervals was measured using an electronic weighting balance to evaluate the permeate flux $(J)$ which was expressed as Equation (2):

$$
J=\frac{V}{A \times t}
$$

where $V$ is the volume of permeate water $(L)$, A is the effective area $\left(\mathrm{m}^{2}\right)$ and $t$ is the running time (h)

\subsubsection{Functional Group Analysis}

Raman spectroscopy was carried out in a DXR Raman microscope (Thermo Fisher Scientific Inc., Madison, WI, USA) using a laser excitation wavelength of $780 \mathrm{~nm}$ of laser power. The experiments were operated through an aperture of 50-micron slit and a 10X-objective lens with a laser spot of $3.1 \mu \mathrm{m}$. Raman spectra were obtained using a 2 s exposure time with 32 accumulations.

\subsection{Antibacterial Test}

\subsubsection{E. Coli Strains and Growth Condition}

E. coli were obtained from multiple tube fermentation technique by the standard protocol of the most probable number of coliform organism test (MPN) for gas and acid productions [22]. First, three different volumes of water sample $(10,1$ and $0.1 \mathrm{~mL})$ were transferred into each of five Durham tubes containing $10 \mathrm{~mL}$ of lactose broth (LB) and incubated at $35^{\circ} \mathrm{C}$ for $48 \mathrm{~h}$ (ULM 600, Memmert, Schwabach, Germany). The solution from the test tubes showing gas production was transferred to a new tube containing brilliant green lactose bile broth (BGLB) and incubated overnight at $35^{\circ} \mathrm{C}$. Then, $0.1 \mathrm{~mL}$ of the BGLB was spread on nutrient agar (NA) plate before incubated at $37^{\circ} \mathrm{C}$ for $24 \mathrm{~h}$. The isolated colonies, identified as E. coli, were further restreaked onto an NA plate until a single colony is obtained. Once purified, the isolates were maintained in liquid nutrient broth (NB) at $4{ }^{\circ} \mathrm{C}$. This suspension was used for antibacterial and biofilm inhibition tests. 


\subsubsection{Antibacterial Test}

The experiment was modified from Liu, Yao, Ren, Zhao, and Yuan (2018) [1]. First, the membrane $\left(1.5 \times 1.5 \mathrm{~cm}^{2}\right)$ was immersed into the suspension of E. coli cells (pre-adjusted with liquid NB to obtain the initial concentration of $10^{6} \mathrm{CFU} / \mathrm{mL}$ ) with NB in 24 well-plates. Then, the well plates were incubated at $37{ }^{\circ} \mathrm{C}$ for $48 \mathrm{~h}$. The membranes were rinsed gently with $0.85 \% \mathrm{NaCl}$ twice to remove the excess E. coli suspensions and non-adhered cells. The membranes were then transferred into sterile test tubes containing $10 \mathrm{~mL}$ of $0.85 \% \mathrm{NaCl}$ before vortex mixing for $1 \mathrm{~min}$ to detach the cells. Finally, $0.1 \mathrm{~mL}$ of cell suspension was spread on NA plate and incubated overnight at $37^{\circ} \mathrm{C}$. The number of viable cells on the membrane was expressed as colony forming unit $(\mathrm{CFU} / \mathrm{mL})$. Data were obtained from three wells, each of which contained a single piece of membrane, and represented as a mean and standard deviations.

\subsubsection{Biofilm Inhibition Test}

The biofilm inhibition test was conducted to determine the performance of the modified membranes to inhibit biofilm formation on surface by measuring the biomass of biofilm. The pre-weighed membranes $\left(1.5 \times 1.5 \mathrm{~cm}^{2}\right)$ were immersed into the suspension of $E$. coli cells in a similar manner to the antibacterial test, but the incubation time was increased to $72 \mathrm{~h}$ to allow biofilm formation. The membranes were rinsed with DI water to remove the loosely bound cells. The membranes were oven-dried at $60{ }^{\circ} \mathrm{C}$ for $1 \mathrm{~h}$ followed by air-drying. The weight of the membrane was measured by a digital weight balance (UMX2, Mettler Toledo, Greifensee, Switzerland). Biofilm mass was determined by the difference between the weight of the membrane before and after being immersed into the suspension of E. coli cells [23]. Data were obtained from three different pieces of membrane, and represented as a mean and standard deviations.

\section{Results and Discussion}

\subsection{Hydrophilic Membrane Modification}

\subsubsection{Water Contact Angle (WCA)}

(a) Effect of coating time

WCA was measured to evaluate the membrane hydrophilicity that plays a significant role in membrane permeability [24]. The results showed that the WCAs of the original PVDF membrane $\mathrm{M} 1$ and the modified membrane M2, M3, and M4 were $84.0^{\circ} \pm 2.1^{\circ}, 86.3^{\circ} \pm 1.7^{\circ}, 86.7^{\circ} \pm 0.5^{\circ}$ and $35.2^{\circ} \pm 1.6^{\circ}$, respectively (Figure 2). The WCA of M4 was decreased to be lower than that of M2 and $\mathrm{M} 3$ due to higher $\mathrm{TiO}_{2}-\mathrm{NP}$ and AgNP content. This could result from the longest coating time for M4, which allows more $\mathrm{TiO}_{2}-\mathrm{NP} / \mathrm{AgNP}$ to attach on the membrane surface as shown in SEM results in the previous section (Figure 2). Furthermore, polyetherethersulfone incorporated with AgNP exhibited the increased hydrophilicity, leading to the increase of water permeability associated with higher affinity [25]. This was because of high specific surface area and fraction of nanoparticles that provide specific functionality to the modified membrane for facilitating the hydrophilicity and permeability. Therefore, the results indicated that the coating time of $24 \mathrm{~h}$ can improve the membrane hydrophilicity.

(b) Effect of $\mathrm{TiO}_{2}-\mathrm{NP} / \mathrm{AgNP}$ concentration

The results of WCAs of the original membrane (M1) and $\mathrm{TiO}_{2}-\mathrm{NP} / \mathrm{AgNP}$ modified membranes (M4-M6) by varied nanoparticle concentrations were illustrated in Figure 2. The WCA of M1 was 84.0 $\pm 2.1^{\circ}$ due to the hydrophobic property of the original membrane. As $\mathrm{TiO}_{2}-\mathrm{NP} / \mathrm{AgNP}$ were introduced into the membranes, the WCA were decreased to $35.2^{\circ} \pm 1.6^{\circ}(\mathrm{M} 4), 35.3^{\circ} \pm 1.4^{\circ}$ (M5) and $70.4^{\circ} \pm$ $3.0^{\circ}$ (M6) for the nanoparticle ratios of $10 \mathrm{ppm} \mathrm{TiO}_{2}-\mathrm{NP} / 10 \mathrm{ppm}$ AgNP, $10 \mathrm{ppm} \mathrm{TiO}{ }_{2}-\mathrm{NP} / 20 \mathrm{ppm}$ $\mathrm{AgNP}$ and $20 \mathrm{ppm} \mathrm{TiO}{ }_{2}-\mathrm{NP} / 10 \mathrm{ppm}$ AgNP, respectively, implying more hydrophilicity. Figure 2 also shows that the WCA of AgNP membrane (control) was decreased to $74.0^{\circ} \pm 0.6^{\circ}$. Since AgNP has high specific surface area and high fraction of surface atom, the adhesion of AgNP on the surface 
can alter the membrane properties to be more hydrophilic and permeable [25]. On the other hand, the $\mathrm{WCA}$ of $\mathrm{TiO}_{2}-\mathrm{NP}$ membrane (control) was increased to $120.4^{\circ} \pm 1.9^{\circ}$. The differences in contact angle between the control $\mathrm{TiO}_{2}-\mathrm{NP}$ and AgNP membranes suggested that the optimal ratio between $\mathrm{TiO}_{2}-\mathrm{NP}$ and AgNP contents could play an important role in the coating and differentiation of WCA. As the contents of $\mathrm{TiO}_{2}-\mathrm{NP} / \mathrm{AgNP}$ were increased to $10 \mathrm{ppm} \mathrm{TiO}-\mathrm{NP} / 20$ ppm AgNP and 20 ppm $\mathrm{TiO}_{2}-\mathrm{NP} / 10$ ppm AgNP for M4 and M5, their WCAs were similarly decreased. This could be due to the agglomeration of $\mathrm{TiO}_{2}-\mathrm{NP}$ and $\mathrm{AgNP}$ from high concentrations; therefore, the WCAs were not decreased even though the AgNP concentration was increased. Moreover, M6 was coated by highest concentration of $\mathrm{TiO}_{2}-\mathrm{NP}$ compared to M4 and M5, but the WCA was slightly decreased compared to the original membrane M1 (Figure 2), which could also result from the excess of $\mathrm{TiO}_{2}-\mathrm{NP}$ on the membrane to cause $\mathrm{TiO}_{2}-\mathrm{NP}$ agglomeration. According to the results, increasing $\mathrm{TiO}_{2}-\mathrm{NP}$ and AgNP concentrations did not decrease the WCA; therefore, using 10 ppm $\mathrm{TiO}_{2}-\mathrm{NP} / 10$ ppm AgNP for M4 coating was adequate to improve the hydrophilicity of the membrane.

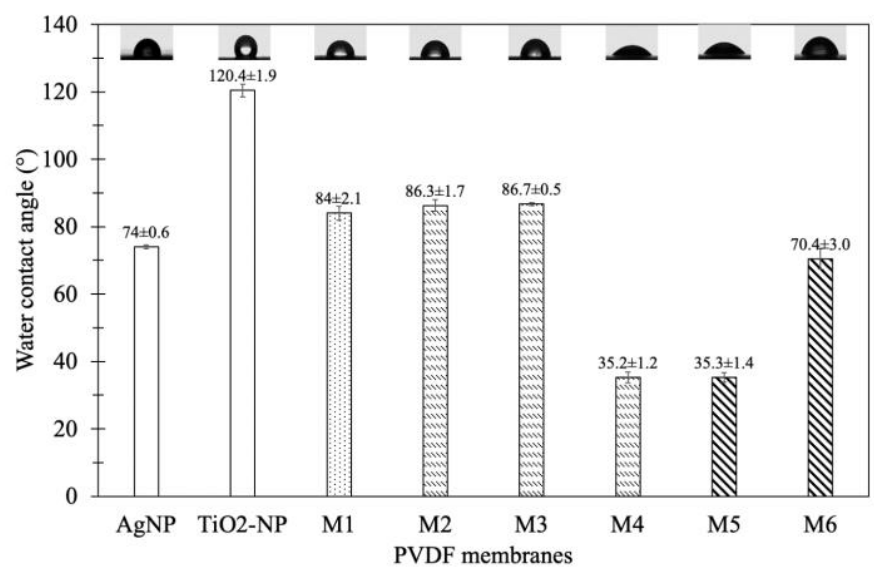

Figure 2. The water contact angle (WCA) of M1 (original), M2 (8 h), M3 (16 h), M4 (24 h) at mixed 10 ppm $\mathrm{TiO}_{2}-\mathrm{NP} / 10$ ppm AgNP, and M5 (10 ppm TiO $2-\mathrm{NP} / 20 \mathrm{ppm}$ AgNP) and M6 (20 ppm $\mathrm{TiO}_{2}-\mathrm{NP} / 10$ ppm $\mathrm{AgNP}$ ) at coating time of $24 \mathrm{~h}$.

\subsubsection{Membrane Morphology}

(a) Effect of coating time

The PVDF membrane was immersed in the solution of 10 ppm $\mathrm{TiO}_{2}-\mathrm{NP}$ and 10 ppm AgNP for varied periods of time to study the effect of coating time on the membrane. The results showed that, compared with the original membrane (Figure 3a), the $\mathrm{TiO}_{2}-\mathrm{NP} / \mathrm{AgNP}$ was observed on the modified membranes (Figure 3b-d), suggesting the successful coating. More particles of $\mathrm{TiO}_{2}-\mathrm{NP} / \mathrm{AgNP}$ were found on the membrane surface when the coating time was increased from 8 to $24 \mathrm{~h}$ for M2 (Figure 3b) and M4 (Figure 3d), respectively. Figure 3b shows that the agglomerated $\mathrm{TiO}_{2}-\mathrm{NP}$ was distributed throughout the surface while AgNP was hardly spotted; however, as the coating time increased, $\mathrm{TiO}_{2}-\mathrm{NP}$ and AgNP were both clearly dispersed and observed on membrane M3 (Figure 3c) and M4 (Figure $3 \mathrm{~d}$ ). In addition, $\mathrm{TiO}_{2}-\mathrm{NP}$ and $\mathrm{AgNP}$ were mostly attached together because these nanoparticles have high surface energy that makes them tend to agglomerate to reach more stable state [26]. EDS mapping of $\mathrm{TiO}_{2}-\mathrm{NP}$ and AgNP distributions on M4 were also carried out and presented in Figure 4 . It can be seen clearly that the distributions of $\mathrm{TiO}_{2}-\mathrm{NP}$ and AgNP were observed on the membrane surface after coating of 10 ppm $\mathrm{TiO}_{2}-\mathrm{NP}$ and $10 \mathrm{ppm}$ AgNP for $24 \mathrm{~h}$ as illustrated in Figure 4a-c. These results supported the successful coating and the layer of $\mathrm{TiO}_{2}-\mathrm{NP}$ and AgNP could improve the hydrophilicity and possibly increase the membrane permeate flux. 


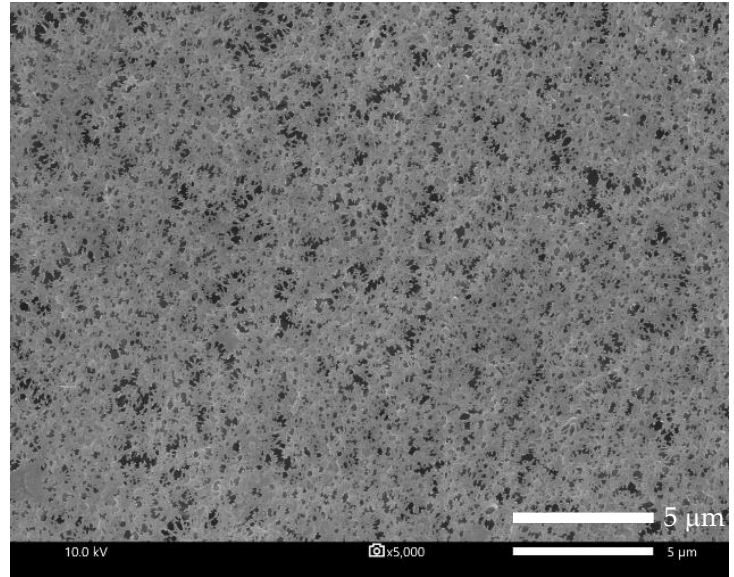

(a)

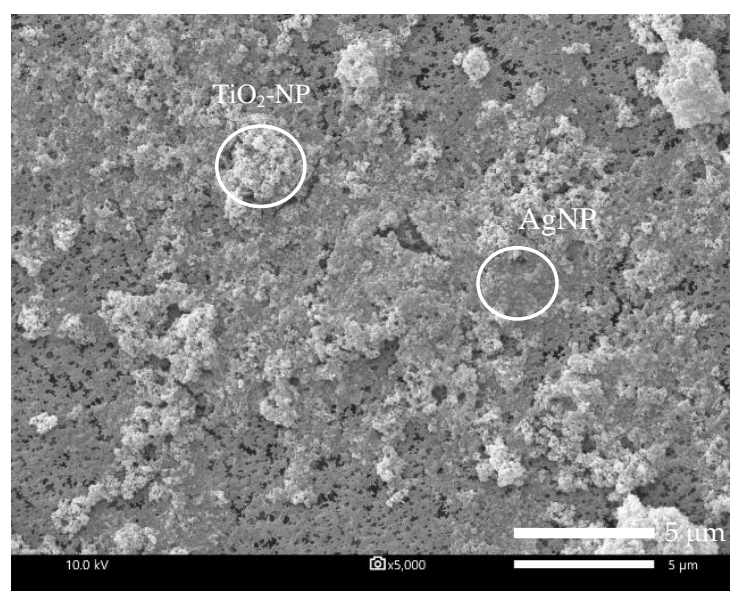

(c)

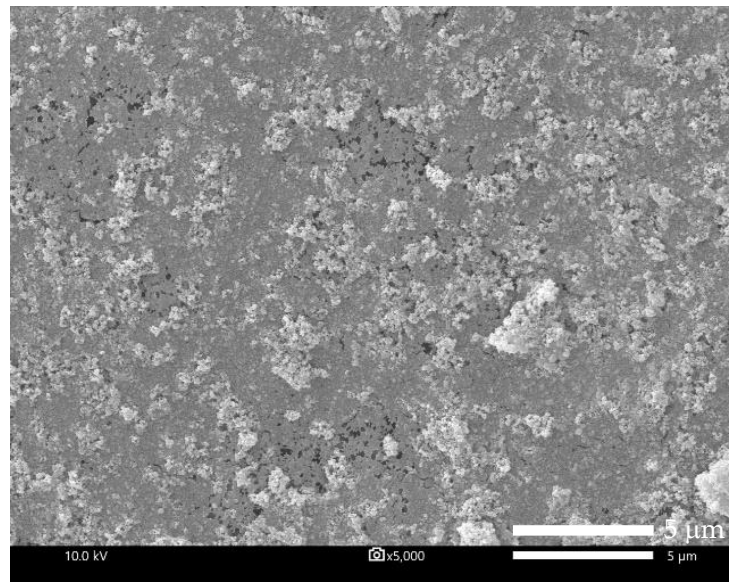

(e)

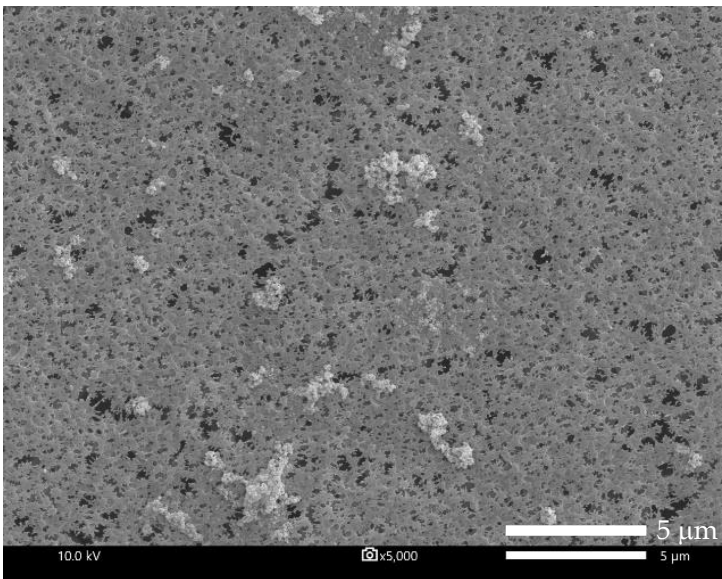

(b)

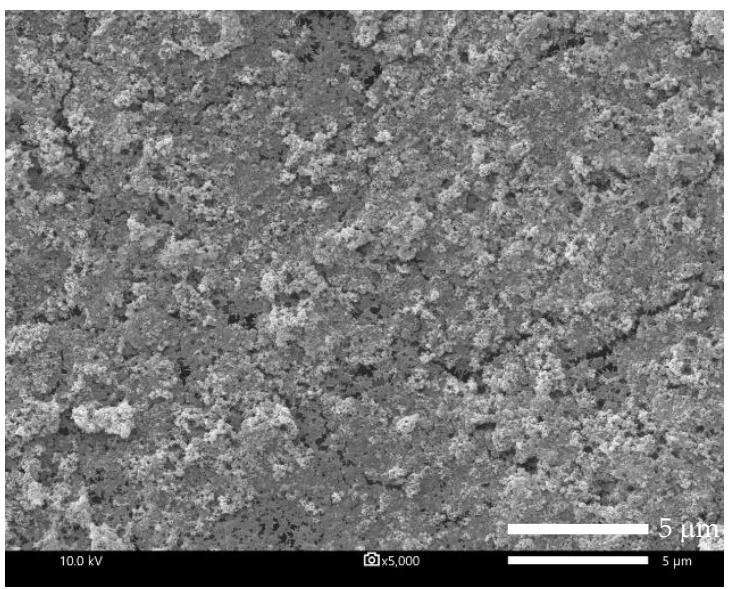

(d)

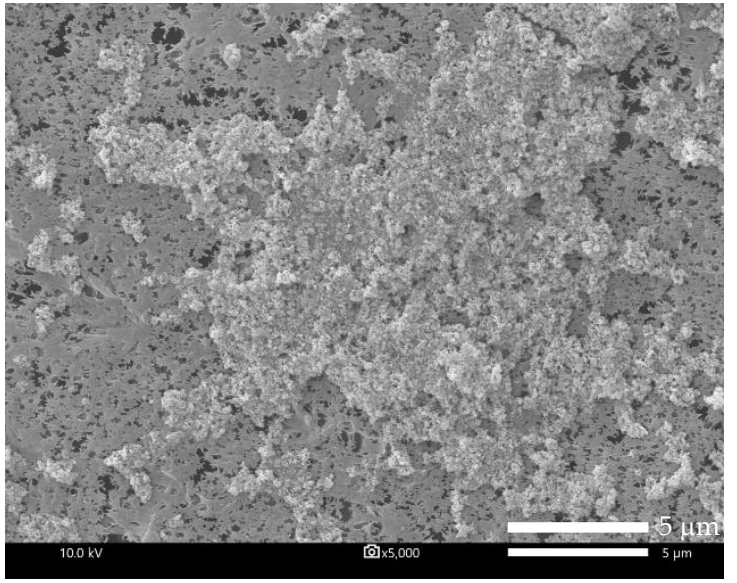

(f)

Figure 3. Scanning electron microscope (SEM) images of the membranes modified by different coating times: (a) M1 (original); (b) M2 (8 h); (c) M3 (16 h); (d) M4 (24 h) at mixed 10 ppm TiO $2-\mathrm{NP} / 10$ ppm $\mathrm{AgNP}$; (e) M5 (10 ppm TiO $-\mathrm{NP} / 20$ ppm AgNP); and (f) $\mathrm{M} 6$ (20 ppm $\mathrm{TiO}_{2}-\mathrm{NP} / 10$ ppm AgNP) at coating time of $24 \mathrm{~h}$ (magnification $\times 5000)$. 


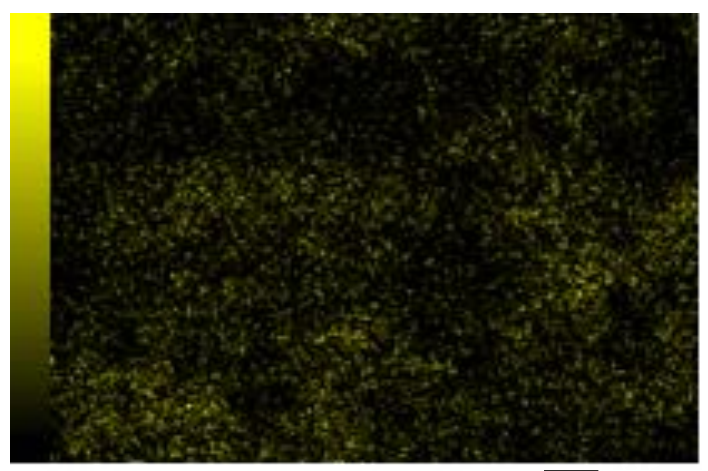

$1 \mu \mathrm{m}$

(a)

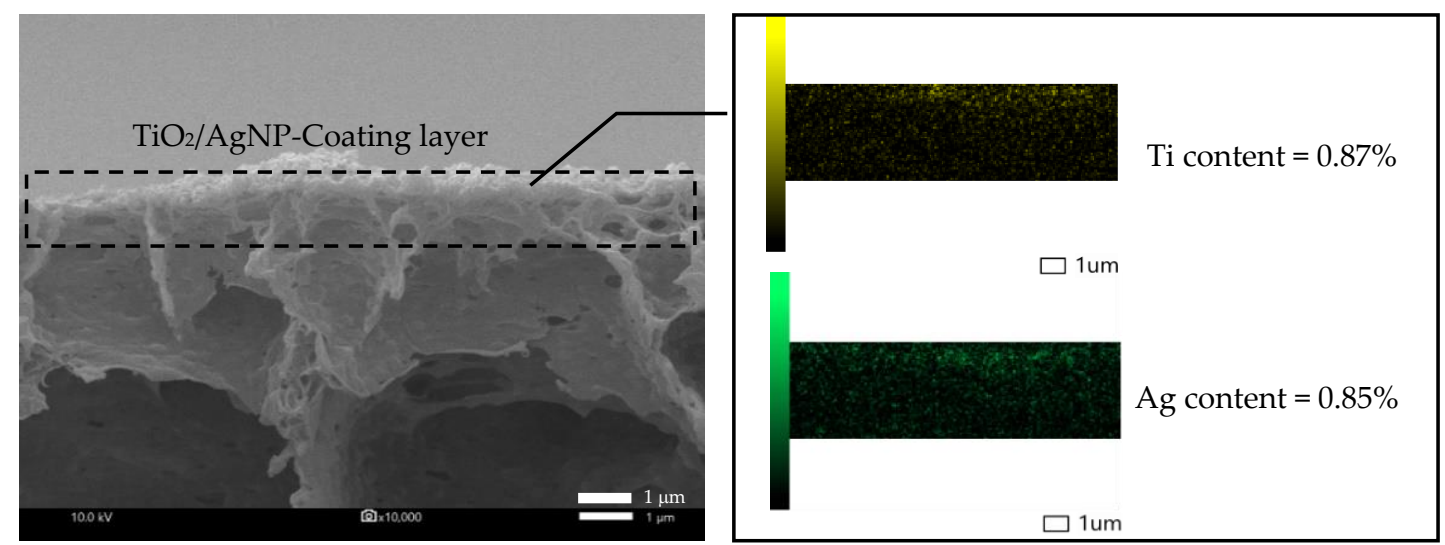

(c)

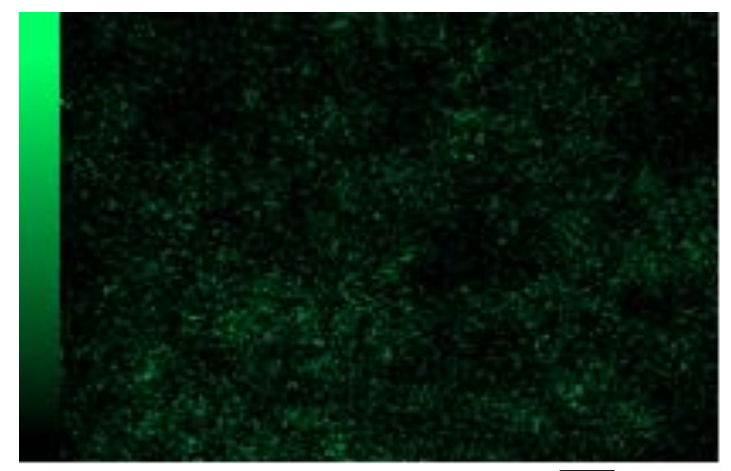

$1 \mu \mathrm{m}$

(b) 
Table 4. Chemical compositions of the modified membranes. (The standard deviation (S.D.) was obtained from 1 sample of each condition).

\begin{tabular}{cccccc}
\hline Membrane & C (\%) & F (\%) & O (\%) & Ti (\%) & Ag (\%) \\
\hline M1 & $55.11 \pm 0.18$ & $43.61 \pm 0.22$ & $1.28 \pm 0.08$ & - & - \\
M2 & $58.16 \pm 0.21$ & $35.05 \pm 0.28$ & $4.36 \pm 0.14$ & $1.39 \pm 0.13$ & $1.03 \pm 0.07$ \\
M3 & $35.89 \pm 0.17$ & $30.42 \pm 0.34$ & $20.51 \pm 0.27$ & $8.33 \pm 0.22$ & $4.84 \pm 0.11$ \\
M4 & $45.02 \pm 0.17$ & $34.42 \pm 0.27$ & $12.65 \pm 0.18$ & $4.29 \pm 0.16$ & $3.62 \pm 0.08$ \\
M4 after & $55.62 \pm 0.07$ & $37.59 \pm 0.11$ & $5.36 \pm 0.06$ & $0.93 \pm 0.02$ & $0.51 \pm 0.01$ \\
M5 & $46.57 \pm 0.18$ & $33.61 \pm 0.30$ & $12.19 \pm 0.20$ & $4.06 \pm 0.16$ & $3.57 \pm 0.09$ \\
M6 & $30.87 \pm 0.16$ & $25.46 \pm 0.31$ & $24.48 \pm 0.30$ & $13.80 \pm 0.26$ & $5.39 \pm 0.11$ \\
\hline
\end{tabular}

Remark: (1) M4 ${ }^{\text {after }}$ is the chemical compositions of membrane after testing with pure water flux. (2) S.D. is varied between different elements and analytical lines and for the same element in different matrices.

(b) Effect of $\mathrm{TiO}_{2}-\mathrm{NP} / \mathrm{AgNP}$ concentration

The morphology of the modified membranes using different nanoparticle concentrations, which were 10 ppm $\mathrm{TiO}_{2}-\mathrm{NP} / 10$ ppm AgNP (M4), 10 ppm TiO $-\mathrm{NP} / 20 \mathrm{ppm}$ AgNP (M5) and 20 ppm $\mathrm{TiO}_{2}-\mathrm{NP} / 10 \mathrm{ppm}$ AgNP (M6), are shown in Figure 3. The smoother surface of the original PVDF membrane (M1) showed that there are no particles on the surface compared with that of the modified membranes, in which a large number of $\mathrm{TiO}_{2}-\mathrm{NP} / \mathrm{AgNP}$ can be observed. When the concentrations of $\mathrm{TiO}_{2}-\mathrm{NP}$ and $\mathrm{AgNP}$ increased, higher distribution of the nanoparticles on the membrane surface can be observed (Figure 3 e-f). Likewise, Yang, Peng, Wang, and Liu (2010) reported that high content of $\mathrm{TiO}_{2}$ concentration motivates the aggregation phenomenon on the membrane surface [27]. Furthermore, the presence of $\mathrm{TiO}_{2}-\mathrm{NP}$ and AgNP on the membranes was confirmed by EDS as reported in Table 4. The results show that the amounts of Ti and $\mathrm{O}$ adhered on M6 were twice as much as M4 and M5 due to higher $\mathrm{TiO}_{2}-\mathrm{NP}$ concentration (20 ppm) used for M6. From the results of WCA (Figure 2) and the $\mathrm{TiO}_{2}-\mathrm{NP}$ and AgNP distribution mappings in Figure 4, it was evident that the WCA was positively correlated to $\mathrm{TiO}_{2}-\mathrm{NP}$ and AgNP content on membrane surface. It could be concluded that the deposited $\mathrm{TiO}_{2}-\mathrm{NP}$ and $\mathrm{AgNP}$ on membrane surface would play important role for enhancing hydrophilicity.

\subsubsection{Surface Roughness}

(a) Effect of coating time

The AFM images of the membrane coated with the solution of $10 \mathrm{ppm} \mathrm{TiO}_{2}-\mathrm{NP}$ and $10 \mathrm{ppm}$ AgNP at different times (8-24 h) are shown in Figure 5. As observed, the original PVDF membrane (M1) exhibits a smooth surface area with the mean surface roughness $\left(R_{a}\right)$ value of $84.7 \mathrm{~nm}$ while M2, M3, and M4 membranes show rougher surface at 79.3, 115.7, and $156.0 \mathrm{~nm}$, respectively, with the increase of coating time. The increase of coating time leads to more agglomeration of $\mathrm{TiO}_{2}-\mathrm{NP} / \mathrm{AgNP}$ particles on the membrane, which could dramatically enhance the surface roughness and, therefore, efficiently increase hydrophilicity. The lower WCA obtained after $\mathrm{TiO}_{2}-\mathrm{NP} / \mathrm{AgNP}$ coating on membrane surface could be due to the enhance surface roughness. According to the Wenzel's model, the wettability of surface is amplified by increasing the surface roughness; in other words, an increase in surface roughness leads to the increase of surface hydrophilicity $[7,28,29]$. 


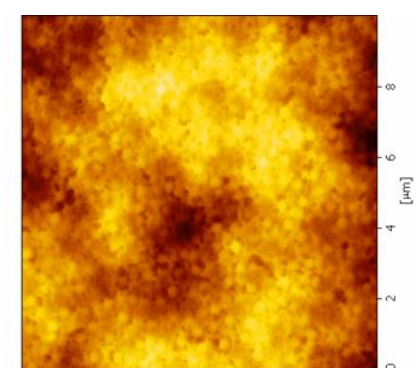

$\mathrm{R}_{\mathrm{a}}=84.7 \mathrm{~nm}, \mathrm{WCA}=84.0 \pm 2.1^{\circ}$

(a)

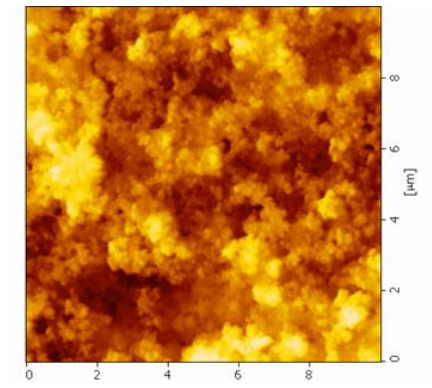

$\mathrm{R}_{\mathrm{a}}=156.0 \mathrm{~nm}, \mathrm{WCA}=35.2^{\circ} \pm 1.6^{\circ}$

(d)

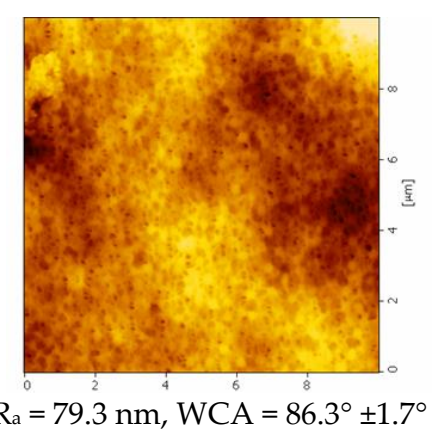

(b)

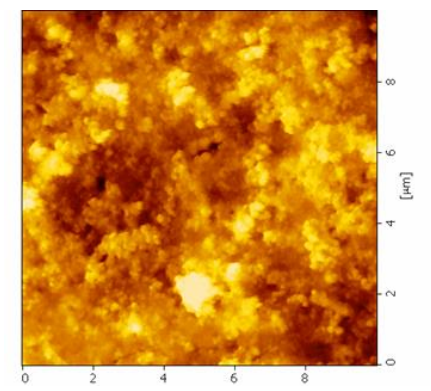

$\mathrm{R}_{\mathrm{a}}=116.3 \mathrm{~nm}, \mathrm{WCA}=35.3^{\circ} \pm 1.4^{\circ}$

(e)

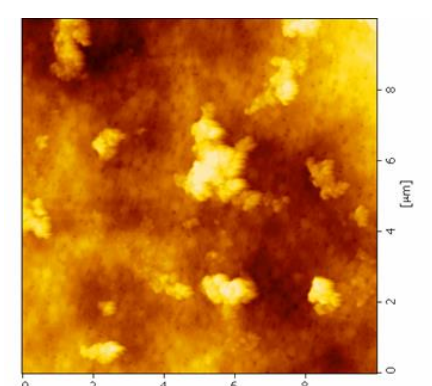

$\mathrm{R}_{\mathrm{a}}=115.7 \mathrm{~nm}, \mathrm{WCA}=86.7^{\circ} \pm 0.5^{\circ}$

(c)

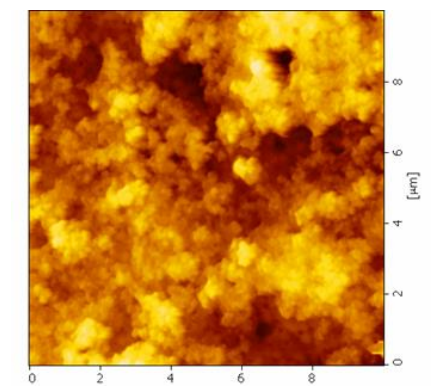

$\mathrm{R}_{\mathrm{a}}=163.0 \mathrm{~nm}, \mathrm{WCA}=70.4^{\circ} \pm 3.0^{\circ}$

(f)

Figure 5. Atomic force microscopy (AFM) image topography of membranes: (a) M1 (original); (b) M2 (8 h); (c) M3 (16 h); (d) M4 (24 h) at mixed 10 ppm TiO $-\mathrm{NP} / 10$ ppm AgNP; (e) M5 (10 ppm $\mathrm{TiO}_{2}-\mathrm{NP} / 20 \mathrm{ppm}$ AgNP); and (f) $\mathrm{M} 6\left(20 \mathrm{ppm} \mathrm{TiO}{ }_{2}-\mathrm{NP} / 10 \mathrm{ppm}\right.$ AgNP) at coating time of $24 \mathrm{~h}$.

(b) Effect of $\mathrm{TiO}_{2}-\mathrm{NP} / \mathrm{AgNP}$ concentration

According to Figure 5, the surface roughness of PVDF flat sheet membrane was also affected by the addition of $\mathrm{TiO}_{2}-\mathrm{NP} / \mathrm{AgNP}$. The AFM images show that the surface of the membranes is rougher compared with the original PVDF membrane like presented in SEM images. $R_{a}$ of M5 and M6 was 116.3 and $163.0 \mathrm{~nm}$, respectively. $R_{a}$ of the modified membrane was increased when the $\mathrm{TiO}_{2}-\mathrm{NP} / \mathrm{AgNP}$ concentration was increased from $10 \mathrm{ppm}$ to $20 \mathrm{ppm}$. There is a difference of high peak and low valley with increasing the $\mathrm{TiO}_{2}-\mathrm{NP} / \mathrm{AgNP}$ concentration. The increase of high peaks leads to higher surface roughness. This could explain the lower contact angle of modified membrane compared with the original membrane, showing higher surface roughness.

\subsubsection{Porosity}

(a) Effect of coating time

The porosities of the original PVDF membrane and the membranes modified by varying coating time are reported in Table 5 and calculated by Equation (1). The results showed that increasing the coating time slightly reduced the porosity of the membrane. The porosity was increased from $61.33 \%$ for the original membrane M1 to $67.19 \%, 67.18 \%$, and $66.74 \%$ for M2, M3, and M4, with the coating time of $8 \mathrm{~h}, 16 \mathrm{~h}$ and $24 \mathrm{~h}$, respectively. This could be explained by the fact that longer coating time resulted in more $\mathrm{TiO}_{2}-\mathrm{NP}$ and $\mathrm{AgNP}$ agglomerations, which increased the opportunity for large particles to block the membrane pores. 
Table 5. Porosity of the membranes.

\begin{tabular}{cc}
\hline Membrane & Porosity (\%) \\
\hline M1 & $61.33 \pm 2.83$ \\
M2 & $67.19 \pm 3.70$ \\
M3 & $67.81 \pm 3.79$ \\
M4 & $66.74 \pm 2.45$ \\
M5 & $66.45 \pm 2.78$ \\
M6 & $64.10 \pm 4.73$ \\
$\mathrm{TiO}_{2}-\mathrm{NP}$ (control) & $65.99 \pm 10.35$ \\
$\mathrm{AgNP}$ (control) & $66.52 \pm 3.35$ \\
\hline
\end{tabular}

(b) Effect of $\mathrm{TiO}_{2}-\mathrm{NP} / \mathrm{AgNP}$ concentration

The porosities of the original PVDF membrane and membranes modified by varying $\mathrm{TiO}_{2}-\mathrm{NP} / \mathrm{AgNP}$ concentrations were shown in Table 5. The modified membranes with the nanoparticle concentrations of $10 \mathrm{ppm} \mathrm{TiO}_{2}-\mathrm{NP} / 10 \mathrm{ppm}$ AgNP (M4), $10 \mathrm{ppm} \mathrm{TiO} \mathrm{T}_{2}-\mathrm{NP} / 20 \mathrm{ppm}$ AgNP (M5), and $20 \mathrm{ppm} \mathrm{TiO}_{2}-\mathrm{NP} / 10 \mathrm{ppm}$ AgNP (M6) provided the increased porosities of $66.74 \% \pm 2.45 \%$, $66.45 \% \pm 2.78 \%$ and $64.10 \% \pm 4.73 \%$, respectively, compared with $61.33 \% \pm 2.83 \%$ of the original PVDF membrane (M1). Previous study has also found that the addition of nanoparticles on the membrane could increase the porosity [30]. However, among the modified membranes, the porosity was decreased when the content of the nanoparticles increased, which might be due to the blockage of membrane pores by the aggregation of nanoparticles [9]. A study found that the addition of $4 \mathrm{wt} \% \mathrm{TiO}_{2}-\mathrm{NP}$ in combination with PVDF and sulfonated polyethgersulfone (PES) exhibited the reduction of water permeability owing to the decreased porosities [31]. In addition, $\mathrm{TiO}_{2}-\mathrm{NP}$ could induce the extremely rapid precipitation and produce a thick dense top layer that can also block the membrane pores [32]. The results indicated that the modified membranes with $\mathrm{TiO}_{2}-\mathrm{NP}$ and $\mathrm{AgNP}$ were improved in their porosity, whereas increasing the $\mathrm{TiO}_{2}-\mathrm{NP} / \mathrm{AgNP}$ concentrations did not induce any porosity improvement.

\subsubsection{Pure Water Flux of Membranes}

Pure water flux of the original and modified PVDF flat sheet membranes was measured at different time intervals under 4 bar of pressure to evaluate the water permeability. Figure 6 exhibits the initial pure water flux ( $t=0$, after setting for $30 \mathrm{~min}$ ) and the results showed that the modified PVDF membrane coated with $\mathrm{TiO}_{2}-\mathrm{NP}$ and $\mathrm{AgNP}$ gave higher flux than that of the original PVDF membrane. The original membrane (M1) gave the lowest initial flux at $444.7 \mathrm{~L} \mathrm{~m}^{-2} \mathrm{~h}^{-1}$ while the M2 and M4 provided the fluxes up to 548.8 and $524.1 \mathrm{~L} \mathrm{~m}^{-2} \mathrm{~h}^{-1}$, respectively. The coating time of $\mathrm{TiO}_{2}-\mathrm{NP}$ and AgNP affected the pure water flux to a greater extent. The presence of hydroxyl functional group from $\mathrm{TiO}_{2}-\mathrm{NP}$ and AgNP contributed to improve the hydrophilicity, thereby improving the pure water flux. M4 had the lowest contact angle (more hydrophilic) but the initial flux was lower than that of M2. This was because the coating time of $24 \mathrm{~h}(\mathrm{M} 4)$ could allow more $\mathrm{TiO}_{2}-\mathrm{NP}$ and $\mathrm{AgNP}$ accumulation on the membrane surface and membrane pores, resulting in the increased membrane thickness and then lower water flux compared to $8 \mathrm{~h}$ (M2). 


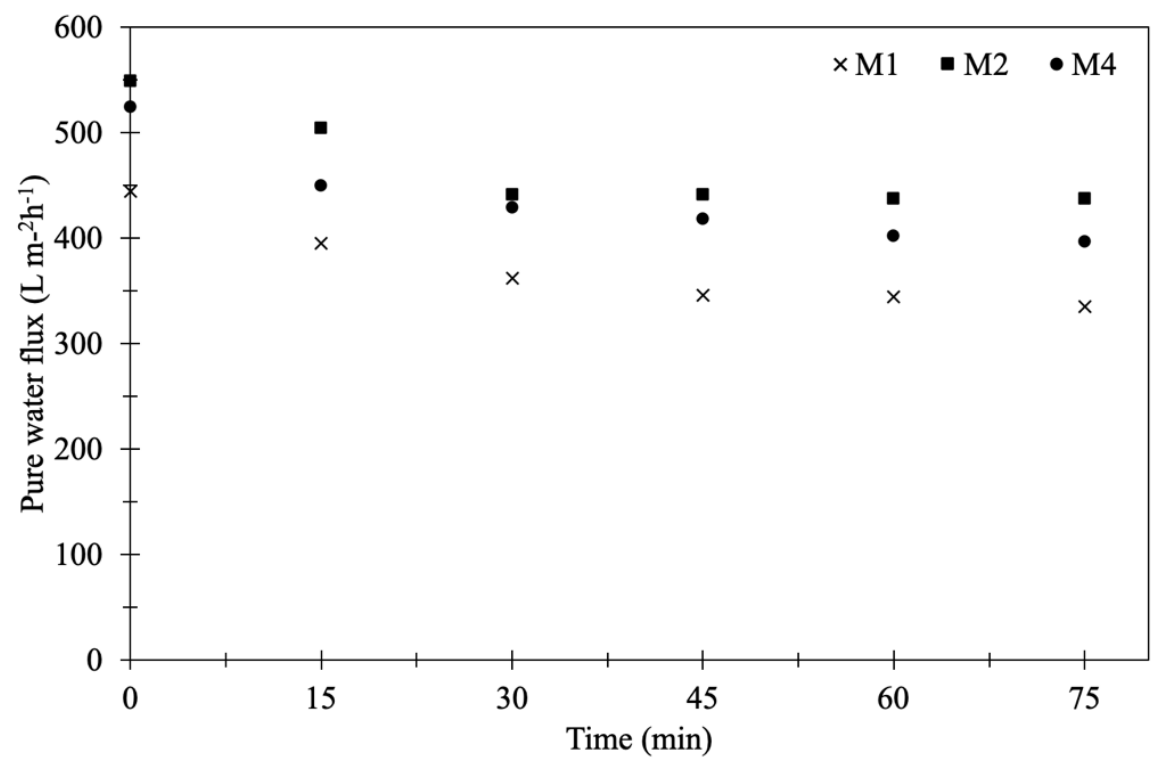

Figure 6. Water fluxes of original PVDF membrane and modified membranes (M1, M2 and M4).

In order to verify the stability and durability of the nanoparticles coated on the PVDF membrane, the original and modified PVDF membranes were tested by water filtration for the period of $75 \mathrm{~min}$ as illustrated in Figure 6. The stable permeate flux of M2 and M4 was higher than that of M1, which was still more than $400 \mathrm{~L} \mathrm{~m}^{-2} \mathrm{~h}^{-1}$. The flux decline was observed after $30 \mathrm{~min}$ and then it was not significant. To determine the durability of $\mathrm{TiO}_{2}-\mathrm{NP}$ and $\mathrm{AgNP}$ layer coated on membrane surface after 75 min water filtration, SEM-EDS of M4 was again measured together with Raman analysis and the result showed that both $\mathrm{TiO}_{2}-\mathrm{NP}$ and $\mathrm{AgNP}$ were still presented on the membrane surface. However, the $\mathrm{Ti}$ and $\mathrm{Ag}$ concentrations before and after the pure water flux test were decreased from $4.29 \%$ to $1.01 \%$ and $3.62 \%$ to $0.55 \%$, respectively, as shown in Table 4 . It was clear that the amount of Ti and Ag might be lost with water, suggesting inadequate stability and durability of nanoparticles on the membrane due to lack of strong chemical bonding on the membrane surface. Figure 7a shows the SEM images of M4 after water filtration, which also confirmed the presence of $\mathrm{TiO}_{2}-\mathrm{NP}$ and $\mathrm{AgNP}$. Raman spectroscopy confirmed that $\mathrm{TiO}_{2}$ was strongly deposited on modified PVDF membrane. The results of original and modified membranes exhibited a number of adsorption bands at $1703 \mathrm{~cm}^{-1}, 1650 \mathrm{~cm}^{-1}$, $1453 \mathrm{~cm}^{-1}, 1100 \mathrm{~cm}^{-1}$, and $840 \mathrm{~cm}^{-1}$, which were attributed to $\mathrm{C}=\mathrm{O}, \mathrm{CH}_{2}$, vibration of $\mathrm{CH}_{2}, \mathrm{CF}_{2}$, CF stretching vibration [33-35], respectively. For the modified membrane, a broad band from 600 to $400 \mathrm{~cm}^{-1}$ was associated with the Ti-O-Ti group and the peak of $443 \mathrm{~cm}^{-1}$ could be assigned to Ti-O-Ti stretching vibration [34]. No difference was observed after Raman shift at $2200 \mathrm{~cm}^{-1}$. The results of Raman analysis along with SEM-EDS confirmed the deposition of $\mathrm{TiO}_{2}-\mathrm{NP}$ on PVDF membrane before and after testing. To improve the durability and retention of nanoparticles on the membrane, the stabilization of those nanoparticles on membrane surface by chemical/plasma activation and crosslinked with polylactic acid might be an effective method to provide the $\mathrm{TiO}_{2}-\mathrm{NP}$ and $\mathrm{AgNP}$ layer stability on membrane surface. 


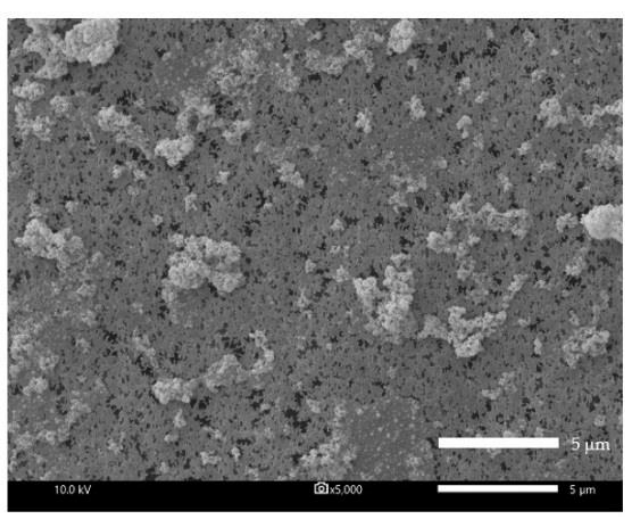

(a)

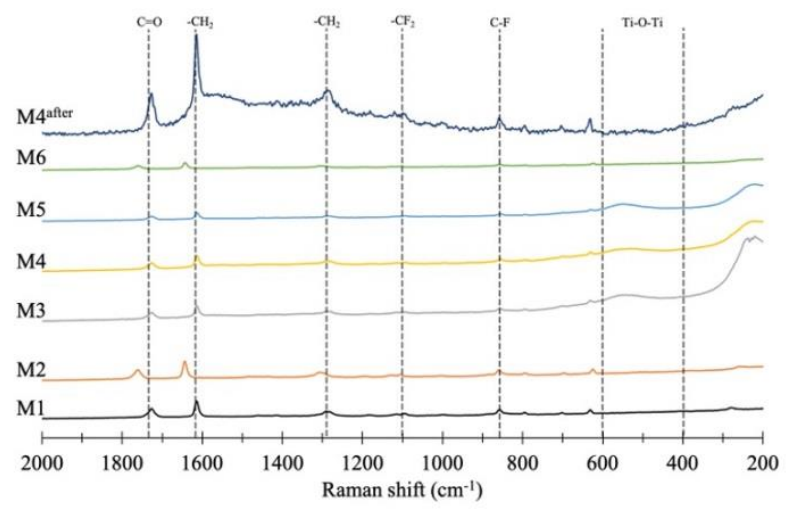

(b)

Figure 7. Morphology and functional groups of membrane after pure water flux testing: (a) SEM image of M4; and (b) Raman spectra of membrane.

\subsection{Antibacterial Properties of Modified Membrane}

\subsubsection{Antibacterial Test}

(a) Effect of $\mathrm{TiO}_{2}-\mathrm{NP} / \mathrm{AgNP}$ concentration

Both $\mathrm{TiO}_{2}-\mathrm{NP}$ and $\mathrm{AgNP}$ are well-known for their antimicrobial properties [36]. $\mathrm{TiO}_{2}-\mathrm{NP}$ can generate reactive oxygen species (ROS), especially under ultraviolet (UV) irradiation, damaging cellular components, e.g., lipid membrane, protein, or DNA [37]. Besides oxidative stress, the released $\mathrm{Ag}^{+}$ could inactivate several enzymes and interact with DNA, resulting in cell death [38]. In this study, the PVDF membranes coated with $\mathrm{TiO}_{2}-\mathrm{NP}$ and AgNP were tested for their antibacterial property to reduce the number of $E$. coli cells.

The number of viable E. coli cells adhered onto PVDF membrane were $1.16 \times 10^{7} \mathrm{CFU} \mathrm{mL}{ }^{-1}$. In this study, the modified membranes showed antibacterial properties under dark condition that the modification of PVDF membrane with either $10 \mathrm{ppm}$ of $\mathrm{TiO}_{2}-\mathrm{NP}$ or AgNP significantly decreased the number of viable cells on the membrane to $0.48 \times 10^{6}$ and $0.89 \times 10^{6} \mathrm{CFU} \mathrm{mL} \mathrm{m}^{-1}$, respectively (Figure 8a). In comparison with $\mathrm{M} 1$, the presence of both $\mathrm{TiO}_{2}-\mathrm{NP}$ and $\mathrm{AgNP}$ (M4) significantly decreased the number of viable cells on the membrane by $90 \%\left(1.11 \times 10^{6} \mathrm{CFU} \mathrm{mL}^{-1}\right)(p$-value $>0.5)$, comparable to those coated with only $\mathrm{TiO}_{2}-\mathrm{NP}$ or AgNP. Increasing the amount of AgNP to $20 \mathrm{ppm}$ $\left(\mathrm{M} 5,0.83 \times 10^{6} \mathrm{CFU} \mathrm{mL}{ }^{-1}\right.$ ) did not significantly affect the antibacterial property of the $\mathrm{TiO}_{2}-\mathrm{NP} / \mathrm{AgNP}$ dip-coated PVDF membrane (M4) ( $p$-value $>0.5$ ). This is possibly due to the similar chemical composition between M4 and M5 (Table 4). On the contrary, a higher amount of $\mathrm{TiO}_{2}-\mathrm{NP}(\mathrm{M} 6$, $3.46 \times 10^{6} \mathrm{CFU} \mathrm{mL}{ }^{-1}$ ) substantially reduced the antibacterial activity of the $\mathrm{TiO}_{2}-\mathrm{NP} / \mathrm{AgNP}$ dip-coated PVDF membrane. The particular antibacterial efficiency depends on their size, shape, and surface areas that would release free radicals for the inactivation of bacterial cells [39]. Even though the higher content of Ti and $\mathrm{Ag}$ was detected on the $\mathrm{M} 6$ membrane (Table 4), too high a $\mathrm{TiO}_{2}-\mathrm{NP}$ concentration led to the agglomeration onto PVDF membrane (Figure $3 \mathrm{f}$ ). This could reduce the contact area between bacterial cells and nanoparticles thus decreasing the antibacterial activity. Similar results have been observed by Soo et al. (2020) in Salmonella Albany LCUM0022 and Bacillus cereus LCUM0001 under contact with $\mathrm{Ag}$ dopant with $\mathrm{TiO}_{2}$ that reduces the microbial growth toward bacterial cell growth inhibition [40]. E. coli cell growth was also decreased with the addition of catalyst under dark condition [41]. This was the permeation of active $\mathrm{TiO}_{2}-\mathrm{NP}$ into bacterial cell during the dark condition, resulting in the agglomeration and attachment at the bacterial membrane [42]. Of all the modified membranes, the results indicated that the mixed solution of $10 \mathrm{ppm} \mathrm{TiO}_{2}-\mathrm{NP}$ and $10 \mathrm{ppm}$ AgNP (M4) was suitable for the antibacterial property. 


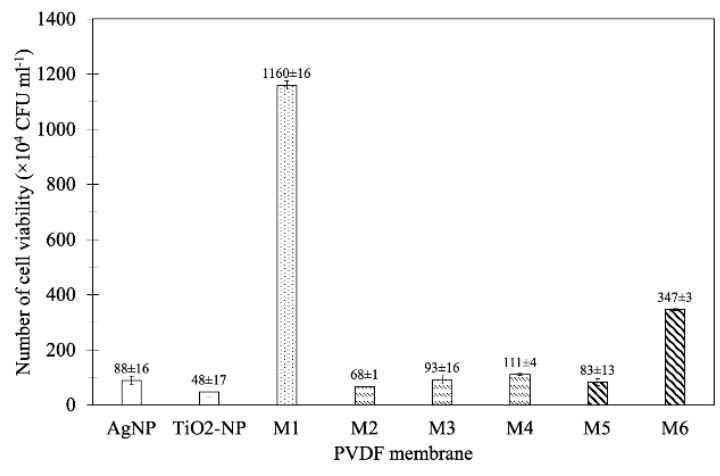

(a)

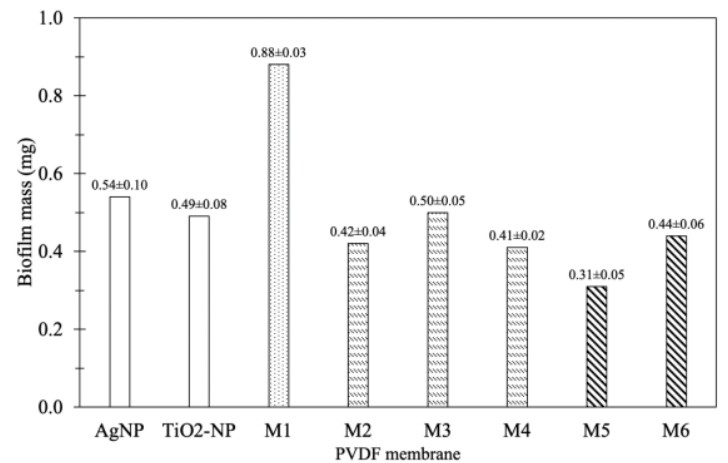

(b)

Figure 8. Antibacterial properties and biofilm inhibition test of membranes: (a) the number of viable $E$. coli cells and (b) biofilm formation on membranes.

(b) Effect of coating time.

The number of $E$. coli cells on the PVDF membranes modified with 10 ppm $\mathrm{TiO}_{2}-\mathrm{NP} / 10 \mathrm{ppm}$ AgNP at various coating times are also presented in Figure 8b. The dipped coating of $10 \mathrm{ppm}$ $\mathrm{TiO}_{2}-\mathrm{NP} / 10$ ppm AgNP onto the PVDF membrane for $8 \mathrm{~h}$ (M2), $16 \mathrm{~h}$ (M3) and $24 \mathrm{~h}$ (M4), reduced the number of adhered cells by $94 \%, 92 \%$, and $90 \%$, respectively. Longer coating time resulted in the lower antibacterial efficiency of the modified membrane even though higher Ti and Ag components were observed (Table 4). This likely caused by the agglomeration of nanoparticles on the modified membrane (Figure 3); therefore, M2 with lower agglomeration could contain more nanoparticle surface area to allow more interaction sites between particles and cells, thereby showing higher antibacterial property than M3 and M4.

\subsubsection{Biofilm Inhibition Test}

(a) Effect of $\mathrm{TiO}_{2}-\mathrm{NP} / \mathrm{AgNP}$ concentration

The effect of nanoparticles-modified membrane on inhibition of biofilm formation, or antifouling property, was evaluated by using the gravimetric method. While $0.88 \pm 0.03 \mathrm{mg}$ of biofilm mass was detected in the unmodified PVDF membrane (M1), the coating of either $\mathrm{TiO}_{2}-\mathrm{NP}$ or AgNP could significantly reduce the amount of biofilm to $0.49 \pm 0.08$ and $0.54 \pm 0.10 \mathrm{mg}$, respectively (Figure $8 \mathrm{~b}$ ). The results are in agreement with the antibacterial property (Figure 8a). The coating of both nanoparticles (M4) decreased the amount of biofilm mass to $0.41 \pm 0.02 \mathrm{mg}$, corresponding to $53 \%$ reduction. In comparison with $\mathrm{M} 4$, the increase of $\mathrm{AgNP}$ to $10 \mathrm{ppm} \mathrm{TiO}-\mathrm{NP} / 20 \mathrm{ppm} \mathrm{AgNP}$ (M5) further reduced the biofilm mass by $65 \%(0.31 \pm 0.05 \mathrm{mg})$. On the other hand, the higher amount of $\mathrm{TiO}_{2}-\mathrm{NP}$ in $\mathrm{M} 6$ did not improve the antifouling property (50\% reduction of biomass). However, compared to either $\mathrm{TiO}_{2}-\mathrm{NP}$ or AgNP-modified membrane, the coating of both $\mathrm{TiO}_{2}-\mathrm{NP}$ or AgNP did not increase the antibacterial property (Figure 8a), yet the synergistic effect on the antifouling property was observed (Figure 8b). Besides the inactivation of bacterial cells, the altered surface hydrophilicity also affects the biofilm formation, i.e., antifouling property of the modified membrane. Ayyaru and Ahn (2018) [32] reported that increasing the hydrophilicity of the membrane surface could increase antifouling properties. Fouling or the formation of biofilm is initiated by the attachment of cells to the surface using the associated organelles such as flagellar and pilli [43]. Once the cells irreversibly attached to the surface, they started to produce EPS substances such as carbohydrates and proteins to form biofilm structure, which could completely block the membrane pores at this stage [44]. It has been proposed that the hydration layer on the hydrophilic surface reduces the adhesion of protein to the surface, resulting in the lower attached cells for biofilm formation [45].

(b) Effect of coating time

Since the antifouling property of PVDF membrane coated with both $\mathrm{TiO}_{2}-\mathrm{NP}$ and AgNP (M4) was more effective than those coated with only $\mathrm{TiO}_{2}-\mathrm{NP}$ or AgNP (Figure 8b), the effect of coating time 
on $\mathrm{TiO}_{2}-\mathrm{NP} / \mathrm{AgNP}$-modified membrane was investigated. The biofilm mass of M2, M3, and M4 were $0.42 \pm 0.04,0.50 \pm 0.05$ and $0.41 \pm 0.02 \mathrm{mg}$, respectively compared to M1 $(0.8751 \pm 0.03)$ as illustrated in Figure 8b. The PVDF membrane modified with 10 ppm $\mathrm{TiO}_{2}-\mathrm{NP} / 10 \mathrm{ppm}$ AgNP reduced biofilm formation by $43-53 \%$. Increasing the coating time $(8,16$, and $24 \mathrm{~h})$ did not affect the antifouling property of the modified membrane since the biofilm mass of M2, M3 and M4 were not significantly different $(p>0.05)$. It should be noted that increasing the coating time also decreased the WCA in this study (Figure 2). Even though it has been found that lower WCA led to more hydrophilic membrane that could inhibit microorganisms adhering to the membrane [46], similar results of the modified membranes in this study suggested that more factors could play a role in antifouling properties.

\section{Conclusions}

In this work, the modified PVDF membrane by $\mathrm{TiO}_{2}-\mathrm{NP} / \mathrm{AgNP}$ dipped coating technique was developed to improve the hydrophilicity of the membrane along with its antibacterial and antifouling properties. The results of SEM and EDS showed that the amount of $\mathrm{TiO}_{2}-\mathrm{NP} / \mathrm{AgNP}$ on the membrane surface increased with longer coating time and higher $\mathrm{TiO}_{2}-\mathrm{NP} / \mathrm{AgNP}$ concentrations. Furthermore, increasing the coating time and $\mathrm{TiO}_{2}-\mathrm{NP} / \mathrm{AgNP}$ concentrations could decrease the WCAs of the modified membranes. Compared with the porosity of $61.33 \% \pm 2.83 \%$ of the original PVDF membrane, the porosity of the modified membranes could be increased up to $66.74 \% \pm 2.45 \%$ using the coating time of $24 \mathrm{~h}$. At this fixed coating time, increasing the nanoparticle concentrations to $20 \mathrm{ppm}$ of $\mathrm{TiO}_{2}-\mathrm{NP}$ and 20 ppm of AgNP could increase the porosities to $64.10 \% \pm 4.73 \%$ and $66.45 \% \pm 2.78 \%$, respectively. Noteworthy antibacterial and antifouling properties of the $\mathrm{TiO}_{2}-\mathrm{NP} / \mathrm{AgNP}$-modified membrane were reported. The modified membranes could reduce the number of adhered E. coli cells by approximately $90 \%$ and the biofilm formation by at least $43 \%$. The PVDF membrane dip-coated in 10 ppm $\mathrm{TiO}_{2}-\mathrm{NP}$ and $10 \mathrm{ppm}$ AgNP for $8 \mathrm{~h}$ showed the highest antibacterial (94\% inactivation) and antifouling properties (65\% reduction); the increased $\mathrm{TiO}_{2}-\mathrm{NP}$ or $\mathrm{AgNP}$ content or coating time did not improve these properties due to the agglomeration of nanoparticles. This modified membrane is a promising alternative for improving membrane-based wastewater treatment.

Author Contributions: All authors proposed the study and participated in writing the manuscript. K.S., P.-u.S., and S.S. carried out the experiment. P.K. and P.T. discussed the antibacterial test and biofilm inhibition test. K.S., P.-u.S. and S.S. carried out the experimental design and membrane investigations. S.S. employed the AFM analysis and pure water flux experiment. S.S., P.T. and P.K. gave the final approval of the version to be submitted. S.S. is reserved for the project investigator. P.P. and M.H. gave the comments and suggestions. P.P. facilitated the membrane device system for water flux experiment. The manuscript was written, read and approved through contributions of all authors. All authors have read and agreed to the published version of the manuscript.

Funding: This work was financially supported by the Commission on Higher Education and Thailand Research Fund (MRG6280181), and Ratchadaphiseksomphot Endowment Fund, Chulalongkorn University. This research work was also partially supported by Chiang Mai University.

Acknowledgments: This work was financially supported by the Commission on Higher Education, Thailand Research Fund (MRG6280181), and Ratchadaphiseksomphot Endowment Fund, Chulalongkorn University. This research work was also partially supported by Chiang Mai University. The authors would like to thank Department of Environmental Science, Faculty of Science, Chulalongkorn University for facility provided. The authors would like to thank Prompong Pienpinijtham, Department of Chemistry, Faculty of Science, Chulalongkorn University for kindly support in Raman spectroscopy analysis.

Conflicts of Interest: The authors declare they have no competing interests.

\section{References}

1. Liu, B.; Yao, T.T.; Ren, L.X.; Zhao, Y.H.; Yuan, X.Y. Antibacterial PCL electrospun membranes containing synthetic polypeptides for biomedical purposes. Colloids Surf. B 2018, 172, 330-337. [CrossRef] [PubMed]

2. Lu, X.H.; Wang, X.K.; Guo, L.; Zhang, Q.Y.; Guo, X.M.; Li, L.S. Preparation of PU modified PVDF antifouling membrane and its hydrophilic performance. J. Membr. Sci. 2016, 520, 933-940. [CrossRef] 
3. Chew, N.G.P.; Zhao, S.S.; Loh, C.H.; Permogorov, N.; Wang, R. Surfactant effects on water recovery from produced water via direct-contact membrane distillation. J. Membr. Sci. 2017, 528, 126-134. [CrossRef]

4. Miao, R.; Wang, L.; Feng, L.; Liu, Z.W.; Lv, Y.T. Understanding PVDF ultrafiltration membrane fouling behaviour through model solutions and secondary wastewater effluent. Desalin. Water Treat. 2014, 52, 5061-5067. [CrossRef]

5. Zeng, K.L.; Zhou, J.; Cui, Z.L.; Zhou, Y.; Shi, C.; Wang, X.Z.; Zhou, L.Y.; Ding, X.B.; Wang, Z.H.; Drioli, E. Insight into fouling behavior of poly(vinylidene fluoride) (PVDF) hollow fiber membranes caused by dextran with different pore size distributions. Chin. J. Chem. Eng. 2018, 26, 268-277. [CrossRef]

6. Chew, N.G.P.; Zhao, S.S.; Wang, R. Recent advances in membrane development for treating surfactant- and oil-containing feed streams via membrane distillation. Adv. Colloid Interface Sci. 2019, 273, 102022. [CrossRef]

7. Zuo, G.Z.; Wang, R. Novel membrane surface modification to enhance anti-oil fouling property for membrane distillation application. J. Membr. Sci. 2013, 447, 26-35. [CrossRef]

8. Aslam, M.; Ahmad, R.; Kim, J. Recent developments in biofouling control in membrane bioreactors for domestic wastewater treatment. Sep. Purif. Technol. 2018, 206, 297-315. [CrossRef]

9. Wu, L.G.; Zhang, X.Y.; Wang, T.; Du, C.H.; Yang, C.H. Enhanced performance of polyvinylidene fluoride ultrafiltration membranes by incorporating $\mathrm{TiO}_{2} /$ graphene oxide. Chem. Eng. Res. Des. 2019, 141, 492-501. [CrossRef]

10. Alammar, A.; Park, S.H.; Williams, C.J.; Derby, B.; Szekely, G. Oil-in-water separation with graphene-based nanocomposite membranes for produced water treatment. J. Membr. Sci. 2020, 603, 118007. [CrossRef]

11. Wang, F.; Dai, J.W.; Huang, L.Q.; Si, Y.; Yu, J.Y.; Ding, B. Biomimetic and Superelastic Silica Nanofibrous Aerogels with Rechargeable Bactericidal Function for Antifouling Water Disinfection. ACS Nano 2020, 14, 8975-8984. [CrossRef] [PubMed]

12. Penboon, L.; Khrueakham, A.; Sairiam, $\mathrm{S}$. $\mathrm{TiO}_{2}$ coated on PVDF membrane for dye wastewater treatment by a photocatalytic membrane. Water Sci. Technol. 2019, 79, 958-966. [CrossRef] [PubMed]

13. Pi, J.K.; Yang, H.C.; Wan, L.S.; Wu, J.; Xu, Z.K. Polypropylene microfiltration membranes modified with $\mathrm{TiO}_{2}$ nanoparticles for surface wettability and antifouling property. J. Membr. Sci. 2016, 500, 8-15. [CrossRef]

14. Madaeni, S.S.; Ghaemi, N. Characterization of self-cleaning $\mathrm{RO}$ membranes coated with $\mathrm{TiO}_{2}$ particles under UV irradiation. J. Membr. Sci. 2007, 303, 221-233. [CrossRef]

15. Moriyama, A.; Yamada, I.; Takahashi, J.; Iwahashi, H. Oxidative stress caused by $\mathrm{TiO}_{2}$ nanoparticles under UV irradiation is due to UV irradiation not through nanoparticles. Chem. Biol. Interact. 2018, 294, 144-150. [CrossRef]

16. Chew, N.G.P.; Zhang, Y.J.; Goh, K.; Ho, J.S.; Xu, R.; Wang, R. Hierarchically Structured Janus Membrane Surfaces for Enhanced Membrane Distillation Performance. ACS Appl. Mater. Interfaces 2019, 11, 25524-25534. [CrossRef]

17. Huang, L.C.; Zhao, S.; Wang, Z.; Wu, J.H.; Wang, J.X.; Wang, S.C. In situ immobilization of silver nanoparticles for improving permeability, antifouling and anti-bacterial properties of ultrafiltration membrane. J.Membr. Sci. 2016, 499, 269-281. [CrossRef]

18. Qi, L.B.; Liu, Z.Y.; Wang, N.; Hu, Y.X. Facile and efficient in situ synthesis of silver nanoparticles on diverse filtration membrane surfaces for antimicrobial performance. Appl. Surf. Sci. 2018, 456, 95-103. [CrossRef]

19. Wang, L.; Ali, J.; Zhang, C.B.; Mailhot, G.; Pan, G. Simultaneously enhanced photocatalytic and antibacterial activities of $\mathrm{TiO}_{2} / \mathrm{Ag}$ composite nanofibers for wastewater purification. J. Environ. Chem. Eng. 2020, 8, 102104. [CrossRef]

20. Zou, Y.J.; Liang, J.; She, Z.; Kraatz, H.B. Gold nanoparticles-based multifunctional nanoconjugates for highly sensitive and enzyme-free detection of E.coli K12. Talanta 2019, 193, 15-22. [CrossRef]

21. Behboudi, A.; Jafarzadeh, Y.; Yegani, R. Enhancement of antifouling and antibacterial properties of PVC hollow fiber ultrafiltration membranes using pristine and modified silver nanoparticles. J. Environ. Chem. Eng. 2018, 6, 1764-1773. [CrossRef]

22. Rompre, A.; Servais, P.; Baudart, J.; de Roubin, M.R.; Laurent, P. Detection and enumeration of coliforms in drinking water: Current methods and emerging approaches. J. Microbiol. Methods 2002, 49, 31-54. [CrossRef]

23. Huang, J.; Wang, H.T.; Zhang, K.S. Modification of PES membrane with $\mathrm{Ag}-\mathrm{SiO}_{2}$ : Reduction of biofouling and improvement of filtration performance. Desalination 2014, 336, 8-17. [CrossRef] 
24. Ghaemi, N. Novel antifouling nano-enhanced thin-film composite membrane containing cross-linkable acrylate-alumoxane nanoparticles for water softening. J. Colloid Interface Sci. 2017, 485, 81-90. [CrossRef] [PubMed]

25. Maheswari, P.; Prasannadevi, D.; Mohan, D. Preparation and performance of silver nanoparticle incorporated polyetherethersulfone nanofiltration membranes. High Perform. Polym. 2013, 25, 174-187. [CrossRef]

26. Gebru, K.A.; Das, C. Removal of bovine serum albumin from wastewater using fouling resistant ultrafiltration membranes based on the blends of cellulose acetate, and $\mathrm{PVP}_{-} \mathrm{TiO}_{2}$ nanoparticles. J. Environ. Manag. 2017, 200, 283-294. [CrossRef] [PubMed]

27. Yang, Z.; Peng, H.D.; Wang, W.Z.; Liu, T.X. Crystallization behavior of poly(epsilon-caprolactone)/layered double hydroxide nanocomposites. J. Appl. Polym. Sci. 2010, 116, 2658-2667.

28. Chew, N.G.P.; Zhao, S.S.; Malde, C.; Wang, R. Superoleophobic surface modification for robust membrane distillation performance. J. Membr. Sci. 2017, 541, 162-173. [CrossRef]

29. Chew, N.G.P.; Zhao, S.S.; Malde, C.; Wang, R. Polyvinylidene fluoride membrane modification via oxidant-induced dopamine polymerization for sustainable direct-contact membrane distillation. J. Membr. Sci. 2018, 563, 31-42. [CrossRef]

30. Abedini, R.; Mousavi, S.M.; Aminzadeh, R. A novel cellulose acetate (CA) membrane using $\mathrm{TiO}_{2}$ nanoparticles: Preparation, characterization and permeation study. Desalination 2011, 277, 40-45. [CrossRef]

31. Rahimpour, A.; Jahanshahi, M.; Rajaeian, B.; Rahimnejad, M. $\mathrm{TiO}_{2}$ entrapped nano-composite PVDF/SPES membranes: Preparation, characterization, antifouling and antibacterial properties. Desalination 2011, 278, 343-353. [CrossRef]

32. Ayyaru, S.; Ahn, Y.H. Fabrication and separation performance of polyethersulfone/sulfonated $\mathrm{TiO}_{2}$ $\left(\mathrm{PES}_{\mathrm{STiO}}\right)$ ultrafiltration membranes for fouling mitigation. J. Ind. Eng. Chem. 2018, 67, 199-209. [CrossRef]

33. Lou, L.H.; Kendall, R.J.; Smith, E.; Ramkumar, S.S. Functional PVDF/rGO/TiO 2 nanofiber webs for the removal of oil from water. Polymer 2020, 186, 122028. [CrossRef]

34. Lihua, L.; Kendall, R.J.; Ramkumar, S. Comparision of hydrophilic $\mathrm{PVA} / \mathrm{TiO}_{2}$ and hydrophobic $\mathrm{PVDF} / \mathrm{TiO} 2$ microfiber webs on the dye pollutant photo-catalyzation. J. Environ. Chem. Eng. 2020, 9, 103914.

35. Chen, X.J.; Huan, G.; An, C.J.; Feng, R.F.; Wu, Y.H.; Huang, C. Plasma-induced PAA-ZnO coated PVDF membrane for oily wastewater treatment: Preparation, optimization, and characterization through Taguchi OA design and synchrotron-based X-ray analysis. J. Membr. Sci. 2019, 582, 70-82. [CrossRef]

36. Bonan, R.F.; Mota, M.F.; Farias, R.M.D.; da Silva, S.D.; Bonan, P.R.F.; Diesel, L.; Menezes, R.R.; Perez, D.E.D. In vitro antimicrobial and anticancer properties of $\mathrm{TiO}_{2}$ blow-spun nanofibers containing silver nanoparticles. J. Ind. Eng. Chem. 2019, 104, 109876. [CrossRef]

37. Sunada, K.; Kikuchi, Y.; Hashimoto, K.; Fujishima, A. Bactericidal and detoxification effects of $\mathrm{TiO}_{2}$ thin film photocatalysts. Environ. Sci. Technol. 1998, 32, 726-728. [CrossRef]

38. Prabhu, S.; Poulose, E.K. Silver nanoparticles: Mechanism of antimicrobial action, synthesis, medical applications, and toxicity effects. Int. Nano Lett. 2012, 2, 32. [CrossRef]

39. Takeshima, T.; Tada, Y.; Sakaguchi, N.; Watari, F.; Fugetsu, B. DNA/Ag nanoparticles as antibacterial agents against gram-negative bacteria. Nanomaterials 2015, 5, 284-297. [CrossRef]

40. Soo, J.Z.; Chai, L.C.; Ang, B.C.; Ong, B.H. Enhancing the Antibacterial Performance of Titanium Dioxide Nanofibers by Coating with Silver Nanoparticles. ACS Appl. Nano Mater. 2020, 3, 5743-5751. [CrossRef]

41. Yang, L.; Ye, F.Y.; Liu, P.; Wang, F.Z. The Visible-Light Photocatalytic Activity and Antibacterial Performance of $\mathrm{Ag} / \mathrm{AgBr} / \mathrm{TiO}_{2}$ Immobilized on Activated Carbon. Photochem. Photobiol. 2016, 92, 800-807. [CrossRef] [PubMed]

42. Dalai, S.; Pakrashi, S.; Kumar, R.S.S.; Chandrasekaran, N.; Mukherjee, A. A comparative cytotoxicity study of $\mathrm{TiO}_{2}$ nanoparticles under light and dark conditions at low exposure concentrations. Toxicol. Res. 2012, 1, 116-130. [CrossRef]

43. Reisner, A.; Haagensen, J.A.J.; Schembri, M.A.; Zechner, E.L.; Molin, S. Development and maturation of Escherichia coli K-12 biofilms. Mol. Microbiol. 2003, 48, 933-946. [CrossRef] [PubMed]

44. Malamis, S.; Andreadakis, A. Fractionation of proteins and carbohydrates of extracellular polymeric substances in a membrane bioreactor system. Bioresour. Technol. 2009, 100, 3350-3357. [CrossRef] 
45. Jimenez-Pardo, I.; van der Ven, L.G.J.; van Benthem, R.A.T.M.; de With, G.; Esteves, A.C.C. Hydrophilic self-replenishing coatings with long-term water stability for anti-fouling applications. Coatings 2018, 8, 184. [CrossRef]

46. Zhu, J.Y.; Hou, J.W.; Zhang, Y.T.; Tian, M.M.; He, T.; Liu, J.D.; Chen, V. Polymeric antimicrobial membranes enabled by nanomaterials for water treatment. J. Membr. Sci. 2018, 550, 173-197. [CrossRef]

Publisher's Note: MDPI stays neutral with regard to jurisdictional claims in published maps and institutional affiliations.

(C) 2020 by the authors. Licensee MDPI, Basel, Switzerland. This article is an open access article distributed under the terms and conditions of the Creative Commons Attribution (CC BY) license (http://creativecommons.org/licenses/by/4.0/). 